\title{
MASTER
}

\section{Performance Characteristics of an Electric-Vehicle Lead-Acid Battery Pack at Elevated Temperatures}

P. Chapman

\section{DO NOT NICROFILM COVER}

April 1, 1982

Prepared for

U.S. Department of Energy

Through an Agreement with

National Aeronautics and Space Administration

by

Jet Propulsion Laboratory

California Institute of Technology

Pasadena, California

(JPL PUBLICATION 82-25) 


\section{DISCLAIMER}

This report was prepared as an account of work sponsored by an agency of the United States Government. Neither the United States Government nor any agency Thereof, nor any of their employees, makes any warranty, express or implied, or assumes any legal liability or responsibility for the accuracy, completeness, or usefulness of any information, apparatus, product, or process disclosed, or represents that its use would not infringe privately owned rights. Reference herein to any specific commercial product, process, or service by trade name, trademark, manufacturer, or otherwise does not necessarily constitute or imply its endorsement, recommendation, or favoring by the United States Government or any agency thereof. The views and opinions of authors expressed herein do not necessarily state or reflect those of the United States Government or any agency thereof. 


\section{DISCLAIMER}

Portions of this document may be illegible in electronic image products. Images are produced from the best available original document. 


\title{
Performance Characteristics of an Electric-Vehicle Lead-Acid Battery Pack at Elevated Temperatures
}

\author{
P. Chapman
}

$\mathrm{DOE} / \mathrm{CS} / 54209--8$

DE82 013327

This hook was prepared as an account of work sponsored by an ageney of the United States Government. Neither the United States. Covernment nor any agencr thereel. nor any of their employees, makes any

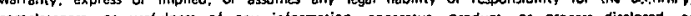

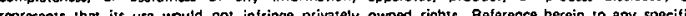

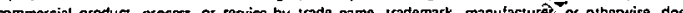
not necessarily onstivte or imply ins endorsement, recommendation of tarosing by the United States Government or any abency thereof. The viaws and opinions of authors expressed herein do not

April 1, 1982

Prepared for

U.S. Department of Energy

Through an Agreement with

National Aeronautics and Space Administration

by

Jet Propulsion Laboratory

California Institute of Technology

Pasadena, California

(JPL PUBLICATION 82.25) 
Prepared by the Jet Propulsion Laboratory, California Institute of Technology, "for the U.S: Department of Energy through an agreement with the National Aeronautics and Space Administration.

This report was prepared as an account of work sponsored by an agency of the United States Government. Neither the United States.Government nor any agency thereof, nor any of their employees, makes any warranty, express or implied, or assumes any legal liability or responsibility for the accuracy, completeness, or usefulness of any information, apparatus, product, or process disclosed, or represents that its use would not infringe privately owned rights.

Reference herein to any specific commercial product, process. or service by trade name, trademark, manufacturer, or otherwise, does not necessarily constit ute or imply its endorsement, recommendation, or favoring by the United States Government or any agency thereof. The views and opinions of authors expressed herein do not necessarily state or reflect those of the United States Government or any agency thereof.

Work conducted through NASA Task RD-152, Amendment 170 and Sponsored by the U.S. Department of Energy under Interagency Agreement DE-A101-78CS54209. 
Data are presented for discharge testing of an 18-Exide IV electric car battery pack over initial electrolyte temperature variations between 27 and $55^{\circ} \mathrm{C}$. The tests were conducted under laboratory conditions and then compared to detailed electric vehicle simulation models. Results showed that battery discharge capacity increased with temperature for constant current discharges, and that battery energy capacity increased with temperature for constant power discharges. Dynamometer test of the GE Electric Test Vehicle showed an increase in range of $25 \%$ for the highest electrolyte temperature. 
This report is a technical presentation of a more general paper titled "Elevated Temperature Lead-Acid Battery Pack Testing," by J.E. Graf, J.F. Toczylowski, and C.P. Chapman, presented at the Electric Vehicle Council Symposium VI, Baltimore, Maryland, October 1981.

The author wishes to thank John Brennand of General Research Corporation for his critical review of this report; his comments and suggestions were quite helpful. In addition, thanks are due to Joe Toczylowski for his thorough and responsible efforts. in conducting these tests and for his efforts in coauthoring the original test report. Also, the author would like to thank Jim Graf for his helpful suggestions in organizing this report.

This study was conducted by the System Modeling and Simulation Section of the Electric and Hybrid Vehicle System Research and Development Project through NASA Task RD-152, Amendment 170. It was sponsored by the U.S. Department of Energy under Interagency Agreement DE-AI01-78cS54209. 
I. INTRODUCTION ....................... 1-1

II. SCOPE OF TESTS . . . . . . . . . . . . . . . . 2-1

III. TEST OBJECTIVES AND PURPOSE . . . . . . . . . . . . . 3-1

IV. TEST CONFIGURATION . . . . . . . . . . . . . . . 4-1

V. RESISTIVE LOAD TESTS AND ANALYSES . . . . . . . . . . . 5-1

VI. VEHICLE LOAD TESTS AND ANALYSES . . . . . . . . . . . . 6-1

VII. COMMENTS, CONCLUSIONS AND RECOMMENDATIONS $. . . \cdot . \cdot . \cdot . \cdot$.

VIII. REFERENCES . . . . . . . . . . . . . . . . . . 8-1 APPENDICES

A. TEST NUMBERS AND SEqUENCES .............. A-1

B. CONSTANT CURRENT DISCHARGE EQUATION DEVELOPMENT....$\quad$ B-1

C. DISCHARGE EQUATION FOR ALL LEAD-ACID BATTERIES . . . . . C-1

\section{$\underline{\text { Figures }}$}

4-1. Test Configuration ................ 4-1

5-1. Ampere/Hourc Versus Starting Electrolyte Temperature . . 5-3

5-2. Cutoff Time Versus Starting Temperature ........ 5-4

5-3. Ampere/Hours as a Function of Discharge Current and Temperature .............. 5-6

5-4. Discharge Time as a Function of Discharge Current and Temperature, Hours ... . . . . . . . . . . 5-7 
5-5. Electrolyte Temperature Risé. . . . . . . . . 5-8

6-1. Specific Power Versus Cutoff Time .......... 6-3

6-2. Discharge Time at Constant Power as a Function of Specific Time and Temperature ........... 6-5

$\underline{\text { Tables }}$

5-1. Resistive Load Test Data . . . . . . . . . 5-2

5-2. Curve Fit-to-Test Data Differences, Ampere-Hours

Versus Temperature and Current........... 5-5

5-3. Curve Fit-to-Test Data Differences,

Cutoff.Time Versus Temperature and Current . . . . . . 5-5

5-4. Curve Fit-to-Raw Data Differences, Electrolyte Temperature Rise . . . . . . . . . 5-9

6-1. Vehicle Load Test Data . . . . . . . . . 6-2

6-2. Vehicle Load Test Versus Simulation . . . . . . . 6 6

6-3. Vehicle Load Test Discrete Temperature Coefficients --

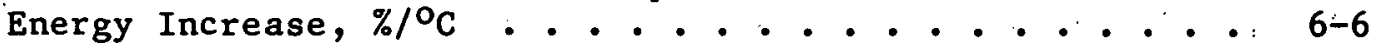


Discharge tests of an 18-Exide IV electric car battery pack were conducted for several initial electrolyte temperatures. The initial temperature was varied between 27 and $55^{\circ} \mathrm{C}\left(80\right.$ and $\left.130^{\circ} \mathrm{F}\right)$. Test data showed that:

(1) Battery discharge capacity (ampere-hours) increased with temperature at approximately $0.9 \% /{ }^{\circ} \mathrm{C}\left(0.5 \% /{ }^{\circ} \mathrm{F}\right)$ for constant current discharges.

(2) Battery energy capacity increased with temperature at rates between 0.8 and $1.13 \% /{ }^{\circ} \mathrm{C}$ for constant power discharges (constant speeds).

(3) Battery energy capacity increased with temperature at rates between 0.65 and $0.88 \% /{ }^{\circ} \mathrm{C}$ for dynamometer tests of the Electric Test Vehicle (ETV-1) on the Society of Automotive Engineers (SAE) J227a D driving schedule. (The ETV-1 was built by General Electric Company for the U.S. Department of Energy.) The vehicle's range increased about $0.9 \% /{ }^{\circ} \mathrm{C}$, or $25 \%$ for the $55^{\circ} \mathrm{C}$ electrolyte temperature.

A detailed electric vehicle simulation was used to determine the various combinations of reduced aerodynamic drag, tire friction, and increased power train efficiency that would result in a $25 \%$ range increase. Genera11y, the average battery output would have to be decreased from about $0.18 \mathrm{kWh} / \mathrm{km}$ to $0.15 \mathrm{kWh} / \mathrm{km}$ for a $25 \%$ range increase.

The results and significance of these elevated temperature tests suggest the need to perform life tests on these types of batteries at elevated temperatures to determine the tradeoff between battery thermal management temperature levels, battery cycle life, and battery life-cycle costs. 


\section{THIS PAGE WAS INTENTIONALLY \\ LEFT BLANK}

2 
SECTION I

INTRODUCTION

One of the main impediments in making an electric vehicle (EV) viable is its range limitation. The range of an EV depends primarily on the amount of energy delivered from its energy source. The lead-acid battery is in wide use today as that energy source because of availability and favorable economics. This battery, however, suffers from relatively low specific power and energy (density).

Recent battery pack tests conducted by the Jet Propulsion Laboratory (JPL) have clearly indicated advantages of operating EV batteries at above normal temperatures (Ref. 1). Bode (Ref. 2) has also indicated that both the specific energy and specific power of individual lead-acid.cells is increased by raising the initial electrolyte temperature of the batteries.

Lead-acid batteries deliver increasing amounts of energy at increasing temperatures because (1) they deliver more charge when discharged at a given constant current, and (2) they deliver it at a slightly higher potential. The potential is higher because all three components of polarization (i.e., activation, resistance, and concentration) are decreased as temperature increases. If the discharge is at a given power profile, a given power is achieved at a slightly lower current because the battery potential is higher due to the lower polarizations. More charge is delivered due to several factors, all of which are related to improved mass transport and conduction within the plates. Electrolyte becomes more available at the active sites due to increased diffusion, and the battery cutoff voltage is reached later because of decreased polarization effects.

The combined effects of these processes have been difficult to predict. Bode gives as a rule of thumb a $1 \%$ increase in capacity (ampere-hour) for each $\left(1.8^{\circ} \mathrm{F}\right) 1^{\circ} \mathrm{C}$ increase in temperature. The Bode data was obtained at low discharge rates and, as such, did not seem directly applicable to electric vehicle operation. The highest discharge rate was $75 \mathrm{~A}$ and the data indicated a significant $18 \%$ increase in cell capacity from 24 to $43^{\circ} \mathrm{C}$ (75 to $\left.109^{\circ} \mathrm{F}\right)$. Bode also found that the temperature influence on capacity increased with higher discharge rates. An EV draws considerably more current (up to $400 \mathrm{~A}$ for the $\mathrm{GE}$ vehicle described below) and, consequently, the temperature effect in an EV could be more pronounced. Recent studies at Southern California Edison (Ref. 3) suggest that the Bode rule of thumb might be closer to $1 \% / 0.6^{\circ} \mathrm{C}\left(1^{\circ} \mathrm{F}\right)$. Also, Vinal reports temperature coefficients varying from 1 to $1.2 \% /{ }^{\circ} \mathrm{C}$ at temperatures of $27^{\circ} \mathrm{C}$ and lower (Ref. 4).

Because the performance of the lead-acid battery improves with temperature, operating the battery at the highest temperature consistent with life requirements is desirable. Bode (Ref. 1, pp. 331-332) references work by Macholl and by Koch and Lander indicating that cycle life increases with operating temperature up to about $45^{\circ} \mathrm{C}$ for SLI batteries discharged at low currents. On the other hand, evidence exists indicating that cell 1 ife decreases with increasing operating temperature (Refs. 5, 6 and 7). Clearly, 
cycle life must be established for electric vehicle lead-acid batteries as a function of operating temperature The influence of temperature on battery life is obviously dependent on the battery design and the failure mechanisms exhibited by that particular type of battery. If the life of the battery is not lessened and does indeed increase with temperature, then operating batteries at elevated temperatures may be the easiest and least expensive way of improving vehicle performance. However, providing the necessary battery temperature control will not be an easy matter. Before any potential rewards can be obtained, an efficient and lightweight thermal management system must be developed. 


\title{
SECTION II
}

\section{SCOPE OF TESTS}

\begin{abstract}
A series of tests was performed to determine the relationship between ampere-hour capacity and energy capacity as a function of initial electrolyte temperature for a total battery pack. JPL selected a set of 18 Exide EV-IV batteries, which are essentially a modified EV-106 (EV-106s serve as a quasistandard EV battery). The tests were split into two major groups: resistive load tests and vehicle tests. The resistive load was a light bank that simulated nearly constant current discharges and the rates were selected to approximate the current requirements of the U.S. Department of Energy's General Electric ETV-1 at 72 and $89 \mathrm{~km} / \mathrm{h}(45$ and $55 \mathrm{mi} / \mathrm{h})$ constant speeds. Initial electrolyte temperatures for these tests were $27,35,45,49$ and $55^{\circ} \mathrm{C}(80$, 95,120 , and $\left.131^{\circ} \mathrm{F}\right)$. Similarly, the vehicle tests were conducted at 72 and $89 \mathrm{~km} / \mathrm{h}(45$ and $55 \mathrm{mi} / \mathrm{h})$ constant speed and the Society of Automotive Engineers (SAE) J227a D urban driving schedule. These tests were conducted at 27,45 , and $55^{\circ} \mathrm{C}\left(80,113\right.$, and $\left.131^{\circ} \mathrm{F}\right)$. The $27^{\circ} \mathrm{C}\left(80^{\circ} \mathrm{F}\right)$ tests were conducted to establish a baseline and were repeated throughout both test series to ensure that no detrimental effects occurred during the higher temperature tests.
\end{abstract}


The objectives (in no particular order of importance) of the elevated temperature battery tests were to:

(1) Determine the relationship between capacity, discharge current and initial electrolyte temperature for constant current discharges.

(2) Determine the relationship between specific power, discharge time, and initial electrolyte temperature for constant power discharge. This relationship is required in the ELVEC ${ }^{1}$ simulation used to predict electric and hybrid vehicle performance (Ref. 8).

(3) Determine the relationship of ending electrolyte temperature to discharge current and starting electrolyte temperatures under laboratory test environments.

(4) Determine the range and energy tradeoffs between the GE ETV-1 employing hot electrolyte and possible road load and propulsion system improvements.

All of the objectives of the test were met and the analytical implications are discussed in this report.

$1_{\text {ELVEC }}$ is an electric and hybrid vehicle performance simulation program developed for the U.S. Department of Energy. Information regarding this program can be obtained through the Electric and Hybrid Vehicle System Research and Development Prnject, Jet Propulsion Laboratory, 4800 Oak Grove Drive, Pasadena, California 91109. 
The 18 batteries under test were housed in a specially built insulated compartment known as the hot box. The compartment was constructed such that heated air could be force-circulated around exposed surfaces of each battery. The air temperature was thermostatically controlled to a pre-set value. Before the start of each test, each of 18 cell temperatures was scanned; discharge tests were not initiated until each temperature was within $1.7^{\circ} \mathrm{C}$ $\left(3^{\circ} \mathrm{F}\right)$ of the desired test temperature. In the same manner, recharges were not initiated until all temperatures were within $1.7^{\circ} \mathrm{C}$ of the initial. temperature. During the discharge tests, an attempt was made to maintain the battery electrolyte temperature. Typical temperature increases were 3 to $4^{\circ} \mathrm{C}$, except for $\mathrm{J} 227 \mathrm{a} \mathrm{D}$ cycle tests, where electrolyte temperature rose between 6 and $12^{\circ} \mathrm{C}$. Due to the need for hydrogen ventilation, only limited temperature control was employed during recharge; typical recharge temperature increases were about $5^{\circ} \mathrm{C}$.

Battery charging was performed by a specially built charge system that provided current limits, temperature-compensated voltage limits, and timed cutoffs. Temperature instrumentation included a multi-channel temperaturesensing system that provided periodic printouts for the electrolyte temperatures of one cell from each battery, as well as printouts for several compartment ambient air temperatures. Precision ampere-hour and Watt-hour meters were used to record the charge and energy associated with each discharge and recharge. Finally, as a backup, strip chart records were maintained for both the total pack voltage and current. The test setup is shown by the block diagram of Figure 4-1.

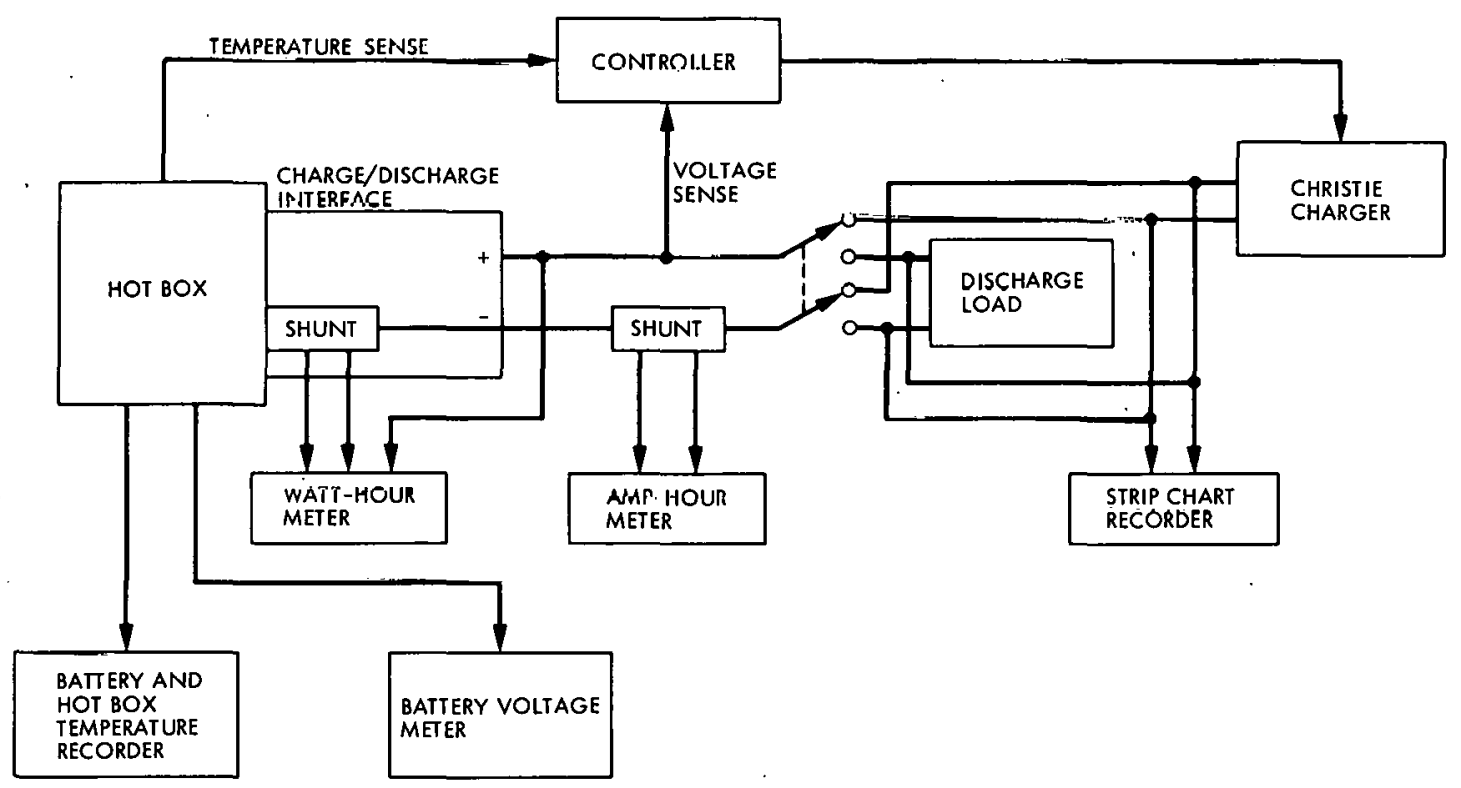

Figure 4-1. Test Configuration 
The insulated compartment was constructed in a manner to allow air flow around all six sides of each battery. Approximately 6 inches of air space was provided under the batteries (the batteries were supported by a metal screen). Twelve fans, strategically placed, forced air up along the sides of the batteries. The heated air was collected in a 6-in. air space above the batteries and recirculated over the heater assembly. The heated air was then forced into the bottom chamber input port and recirculated.

As shown in Figure 4-1, a temperature controller sensed the incoming air and maintained the set temperature to $\pm 0.6^{\circ} \mathrm{C}$. An ampere-hour counter integrated the discharge current and a Watt-hour meter integrated the product of pack current and voltage. A two-channel strip chart recorder was used to record battery current and voltage continuously. Also, a 24-channel recorder was used to record battery module temperatures and air temperatures within the hot box. Finally, a digital voltmeter was used to monitor individual battery voltages but required manual operation.

The variable resitive load was an incandescent light bank that had the capability of dissipating up to $10 \mathrm{~kW}$. Programmable low-voltage cutoff equipment prevented battery discharges below a preselected cutoff voltage leve1.

When using the vehicle as the test bed for the battery pack, a chassis dynamometer provided the proper road load based on previous coastdown and wind tunnel tests of the actual vehicle.

After each test, the pack was recharged using a programmable power supply. with a temperature-sensing circuit that automatically compensated the output voltage based on the temperature sensed at a selected pilot cell. 


\section{SECTION $\mathrm{V}$}

\section{RESISTIVE LOAD TESTS AND ANALYSES}

Table 5-1 lists the results of the tests conducted using the light bank as a load. The light bank approached a pseudo constant current load to the batteries except during the final minutes of the tests. The purpose of these tests were to (1) check out the test system prior to using the vehicle as the test-bed battery load, and (2) determine the curve fit constants relating ampere-hours and cutoff time to discharge current and temperature. These analytical expressions are required to design a thermal management system and predict increased battery performance with increasing electrolyte temperature. The data in Table 5-1 are listed in sequence by nominal starting electrolyte temperature for the two discharge current levels of 75 and $110 \mathrm{~A}$, respectively.

Tables A-1 and A-2a of Appendix A list the test numbers and indicate the sequence of resistive load tests.

Because the insulated compartment was basically designed to heat the batteries, maintaining the relatively low temperature of $27^{\circ} \mathrm{C}$ during discharge was difficult in a closed configuration. This was due primarily to the internal heating of the batteries. In the $27^{\circ} \mathrm{C}$-discharge case, the compartment lid was removed and room-ambient air. was circulated around the batteries. Maintaining the desired test temperature became less difficult as the test temperature increased. The reason for this was that the batteries required additional thermal input to maintain their temperatures. Thus, at high temperatures, the battery pack temperature was maintained reasonably well and not substantially increased.

Figures 5-1 and 5-2 show the results of the resistive load tests. The equations shown in the figures $f$ it the observed data to the accuracy 1 isted in Tables 5-2 and 5-3. The analytical expressions, or plots, can be used to predict capacity or discharge time as a function of discharge current and initial electrolyte temperature over the current and temperature ranges included in the tests. The accuracy of these expressions is unknown beyond the test ranges. Appendix B describes the development of these expressions.

In general, between the temperatures of 27 and $55^{\circ} \mathrm{C}$ and for constant discharge current of: 75 and $110 \mathrm{~A}$, the ampere-hour capacity increased with temperature at a near constant rate of about $0.9 \% /{ }^{\circ} \mathrm{C}$. The same relationship holds true for cutoff (discharge) time. This temperature coefficient appears to be slightly current-dependent over the test range, as shown by the slopes of the lines plotted in Figures 5-1 and 5-2, and these slopes appear to increase slightly with increasing discharge current. However, it would require additional testing at several more discharge currents to determine if there is a slope relationship between the different discharge currents. But for any discharge current between 75 and $110 \mathrm{~A}$, the factor of $0.9 \% /{ }^{\circ} \mathrm{C}$ will predict capacity or discharge time to better than $5 \%$ accuracy, as indicated by Tables 5-2 and 5-3. Of course, different types of lead-acid batteries may have different coefficients, but the form of the equations should be the same. 
Table 5-1. Resistive Load Test Data

\begin{tabular}{|c|c|c|c|c|c|c|c|c|c|c|c|c|}
\hline \multirow{2}{*}{\multicolumn{2}{|c|}{ Current }} & \multicolumn{2}{|c|}{$\begin{array}{l}\text { Nominal } \\
\text { Temper- } \\
\text { ature }\end{array}$} & \multicolumn{3}{|c|}{$\begin{array}{l}\text { Av. Temperature, } \\
{ }^{\circ} \mathrm{C}\end{array}$} & \multirow[b]{2}{*}{$\begin{array}{c}\text { Capacity } \\
\text { A/h }\end{array}$} & \multirow[b]{2}{*}{$\begin{array}{c}\text { Energy, } \\
\text { kWh. }\end{array}$} & \multicolumn{3}{|c|}{ Average } & \multirow[b]{2}{*}{$\begin{array}{l}\text { Discharge } \\
\text { Time, h }\end{array}$} \\
\hline & & ${ }^{\circ} \mathrm{C}$ & ${ }^{\circ} \mathrm{F}$ & Start & End & Rise & & & $\begin{array}{c}\text { Current, } \\
\text { A }\end{array}$ & Voltage & $\begin{array}{l}\text { Power, } \\
\text { W }\end{array}$ & \\
\hline 1 & 75 amp & 26.67 & 80 & 27.29 & 34.81 & 7.52 & 136.91 & 13.78 & 74.005 & 100.64 & 7448 & 1.85 \\
\hline 2 & & & 1 & 26.17 & 29.81 & 3.64 & 130.92 & 13.32 & 71.423 & 101.73 & 7266 & 1.833 \\
\hline 3 & & & & 26.17 & 29.89 & 3.73 & 129.7 & 13.19 & 70.108 & 101.68 & 7129. & 1.85 \\
\hline 10 & & & & 25.42 & 30.86 & 5.44 & 132.6 & 13.68 & 74.369 & 103.16 & 7672 & 1.783 \\
\hline 15 & & 1 & 1 & 28.07 & 31.84 & 3.77 & 135.69 & 13.83 & 74.719 & 101.91 & 7615 & 1.816 \\
\hline 18 & & 35.00 & 95 & 35.35 & 38.64 & 3.29 & 142.91 & 14.62 & 74.587 & 102.29 & 7630 & 1.916 \\
\hline 19 & & 1 & 1 & 34.69 & 37.92 & 3.23 & 143.52 & 14.67 & 71.76 & 102.21 & 7335 & 2.0 \\
\hline 6 & & 45.00 & 113 & 44.94 & 45.86 & 0.92 & 154.28 & 15.88 & 74.675 & 102.92 & 7686 & 2.066 \\
\hline 7 & & 1 & 1 & 44.28 & 46.79 & 2.51 & 153.28 & 15.88 & 74.675 & 102.66 & 7702 & 2.05 \\
\hline 11 & & 55:00 & 131 & 53.84 & 56.36 & 2.51 & 158.65 & 16.3 .3 & 74.378 & 102.92 & 7655 & $2.133^{\circ}$ \\
\hline 12 & & $\dagger$ & $f$ & 54.41 & 55.66 & 1.24 & 158.45 & 16.28 & $74: 285$ & 102.73 & 7632 & 2.133 \\
\hline 4 & $110 \cdot a m p$ & 26.67 & 80 & 25.43 . & $31: 11$ & 5.68 & 119.21 & 11.88 & 110.073 & 99.65 & 10969 & 1.083 \\
\hline 5 & & 1 & 1 & 25.83 & 31.44 & 5.61 & 117.61 & 11.77 & 108.596 & 100.06 & 10867 & 1.083 \\
\hline 16 & & 1 & 1 & 26.02 & 32.60 & 6.58 & 122.19 & 12.18 & $109: 489$ & 100.01 & 10895 & 1.116 \\
\hline 17 & & 35.00 & 95 & 35.28 & 40.94 & 5.67 & 131.77 & 13.17 & 108.363 & 99.94 & 10830 & 1.216 \\
\hline 20 & & 1 & 1 & 35.00 & 40.28 & 5.28 & 131.14 & 13.14 & 109.283 & 100.19 & 10950 & 1.2 \\
\hline 8 & & 45.00 & 113 & 44.81 & 49.09 & 4.28 & 141.13 & 14.23 & 107.241 & 100.82 & 10813 & 1.316 \\
\hline 9 & & 1 & $j$ & 45.08 & 48.51 & 3.43 & 140.3 & 14.19 & 107.923 & 101.23 & 10915 & 1.3 \\
\hline 21 & & 1 & 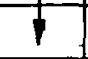 & 45.92 & 49.96 & 4.04 & 143.09 & 14.37 & 108.731 & 100.42 & 10919 & 1.316 \\
\hline 22 & & 48.89 & 120 & 50.49 & 52.64 & 2.15 & 143.63 & 14.46 & 109.141 & 100.66 & 10987 & 1.316 \\
\hline 13 & & 55.00 & 131 & 54.82 & 57.56 & 2.73 & 146.12 & 14.74 & 108.237 & 100.87 & 10918 & 1.35 \\
\hline 14 & & 1 & $\downarrow$ & 55.24 & 57.82 & 2.57 & 146.95 & 14.76 & 107.576 & .100 .44 & 10805 & 1.366 \\
\hline
\end{tabular}




\section{AH WS STAETIHE ELECTFILYTE TEMFEFATUFE*}

(TWO IISEHAFEE. EUFFEHTS

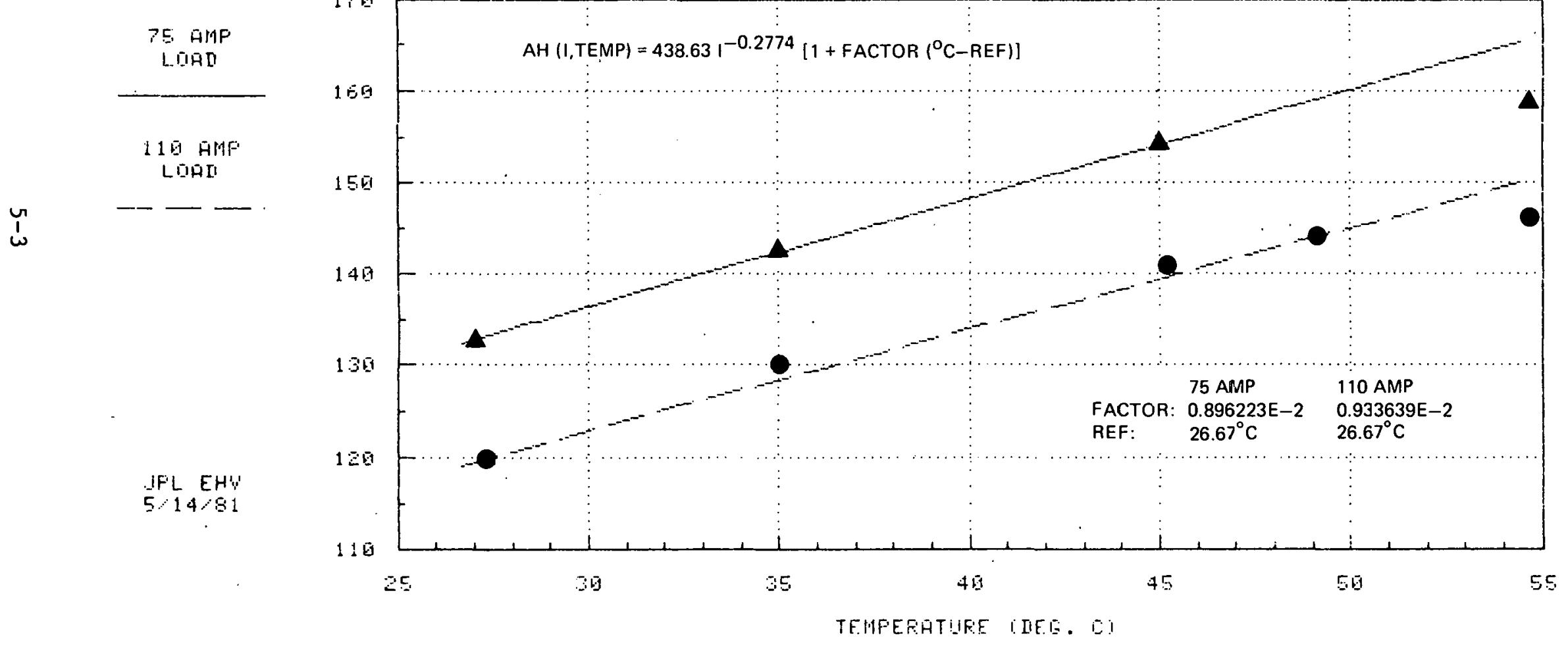

"DATA POINTS INDICATED ARE FROM TABLE 5-2.

Figure 5-1. Ampere-Hours Versus Starting Electrolyte Temperature 


\section{CUTOFF TIME VS STAFTIHE TEMFERATUFE* (TWO DISCHARGE CUFFEHTS)}

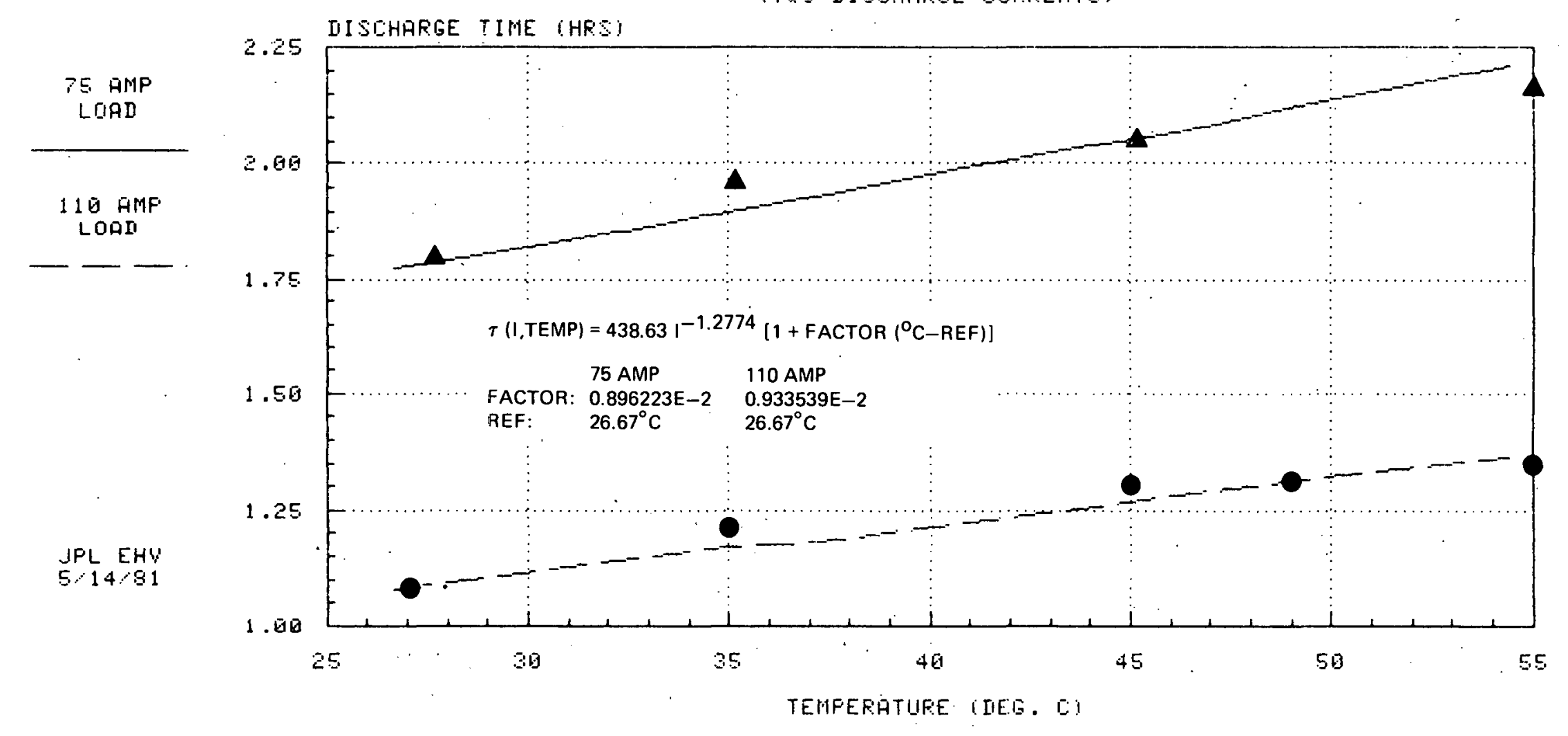

* DATA POINTS INDICATED ARE FROM TABLE $\mathbf{5} \cdot \mathbf{3}$.

Figure 5-2. Cutoff Time Versus Starting Temperature 
Table 5-2. Curve Fit-to-Test Data Differences, Ampere-Hours Versus Temperature and Current

\begin{tabular}{ccccc}
\hline $\begin{array}{c}\text { Load } \\
\text { Current, A }\end{array}$ & Temperature, ${ }^{\circ} \mathrm{C}$ & $\begin{array}{c}\text { Calculated } \\
\text { Ampere-Hours }\end{array}$ & $\begin{array}{c}\text { Measured AV } \\
\text { Ampere-Hours }\end{array}$ & Difference, \% \\
\hline & 27 & 132.42 & 133.16 & -0.56 \\
75 & 35 & 142.31 & 143.22 & -0.64 \\
& 45 & 154.17 & 153.78 & 0.25 \\
110 & 55 & 166.04 & 158.55 & 4.72 \\
& 27 & 119.07 & 119.67 & -0.50 \\
& 35 & 128.33 & 131.46 & -2.38 \\
& 45 & 139.45 & 141.51 & -1.46 \\
& 49 & 143.78 & 143.63 & 0.10 \\
& 55 & 150.57 & 146.54 & 2.75 \\
\hline
\end{tabular}

Table 5-3. Curve Fit-to-Test Data Differences, Cutoff Time Versus Temperature and Current

\begin{tabular}{ccccc}
\hline $\begin{array}{c}\text { Load } \\
\text { Current, A }\end{array}$ & Temperature, ${ }^{\circ} \mathrm{C}$ & $\begin{array}{l}\text { Calculated } \\
\text { Cutoff Time, } h\end{array}$ & $\begin{array}{l}\text { Measured AV } \\
\text { Cutoff Time }\end{array}$ & Difference, \% \\
\hline & 27 & 1.77 & 1.83 & -3.28 \\
& 35 & 1.90 & 1.96 & -3.06 \\
15 & 45 & 2.06 & 2.06 & 0.00 \\
110 & 55 & 2.21 & 2.13 & 3.76 \\
& 27 & 1.08 & 1.09 & -0.92 \\
& 35 & 1.17 & 1.21 & -3.31 \\
& 45 & 1.27 & 1.31 & -3.05 \\
& 49 & 1.31 & 1.32 & 0.88 \\
\hline
\end{tabular}

Figures 5-1 and 5-2 are two-dimensional plots of a three-space relationship, as indicated by the associated expressions illustrated in Figures 5-3 and 5-4. In these figures, the $X$ and $Y$ axes have been scaled to enhance the three-dimensional relationships. The purpose of presenting Figures 5-3 and 5-4 is to stress the fact that the relationships between discharge current, time (or battery capacity), and temperature are not trivial and include two independent variables.

Figure 5-5 shows the relationship between the electrolyte temperature at the end of each test as a function of starting electrolyte temperature and 


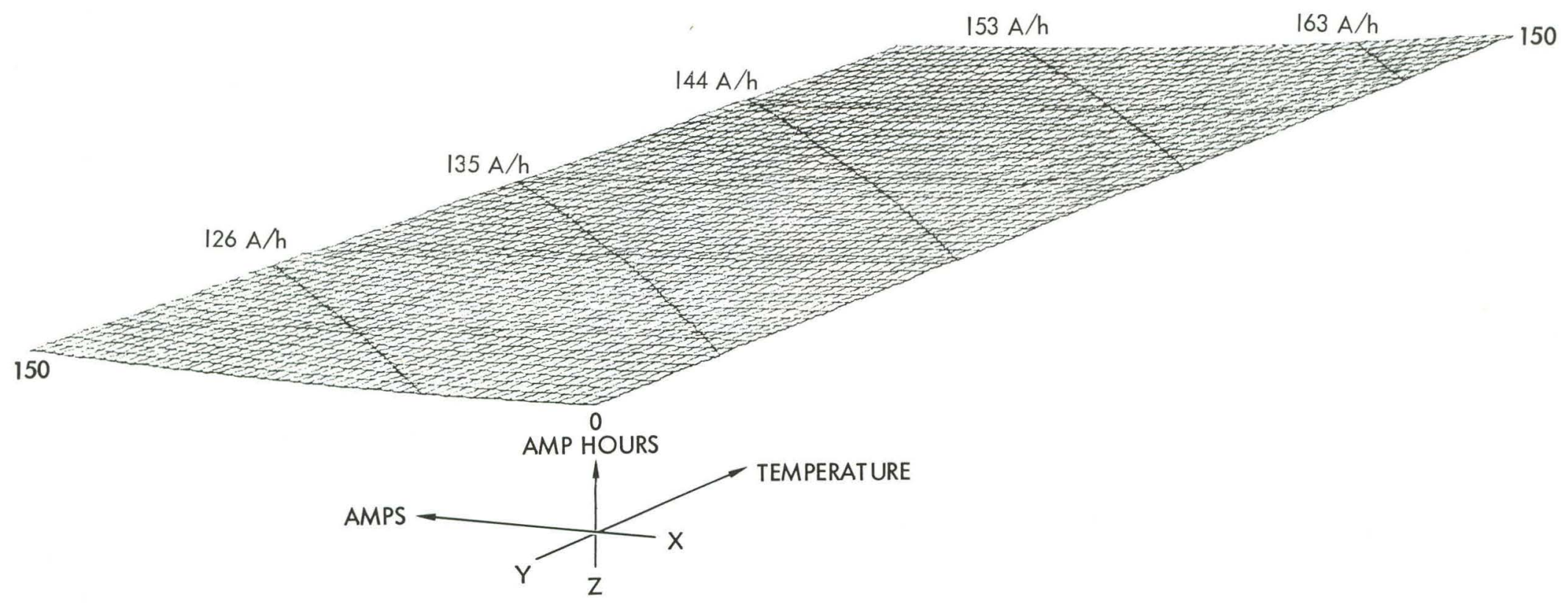

NOTE: X AND Y AXES HAVE BEEN SCALED TO ENHANCE 3-D VIEW.

Figure 5-3. Ampere-Hours as a Function of Discharge Current and Temperature 


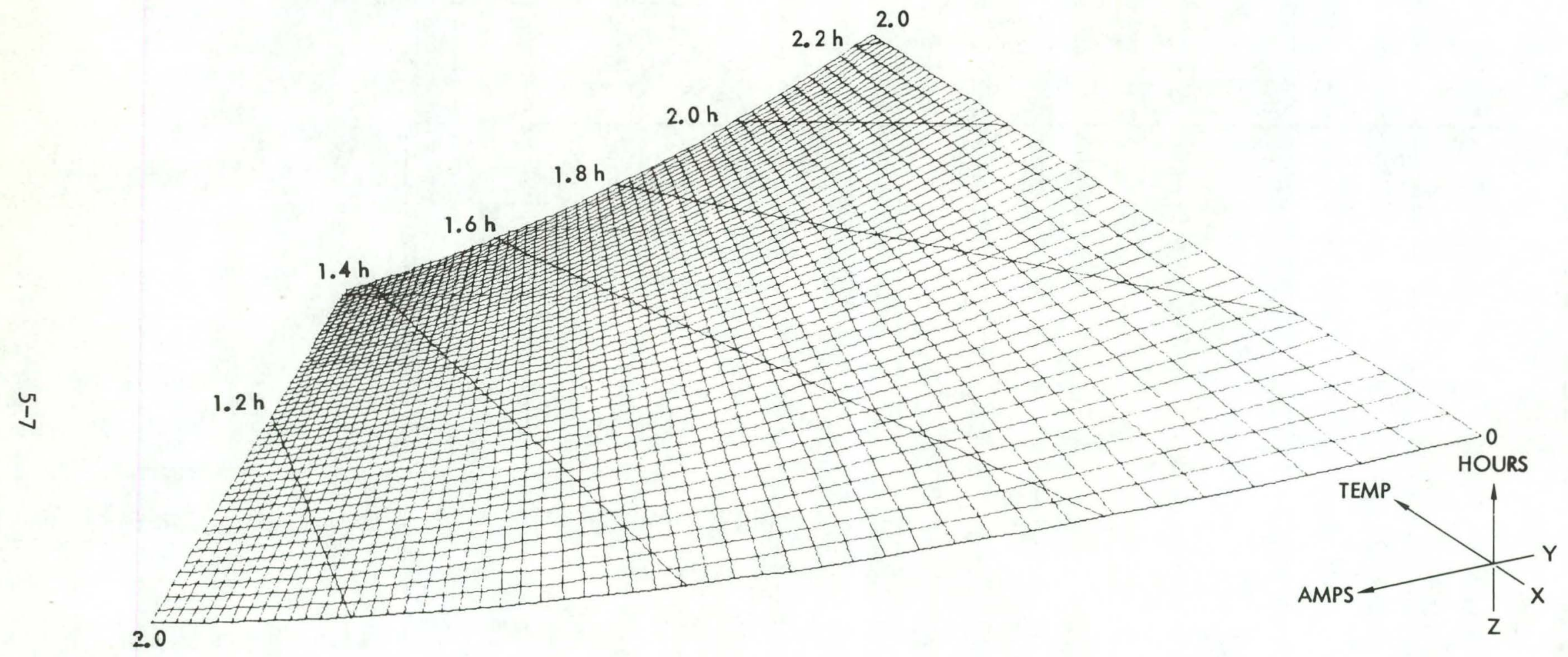

NOTE: X AND Y AXES HAVE BEEN SCALED TO ENHANCE 3-D VIEW.

Figure 5-4. Discharge Time as a Function of Discharge Current and Temperature, Hours 


\section{ELECTROLYTE TEMFERATUEE RISE}

ITUG LOAI CUREEHTS

75 AMP LOAII

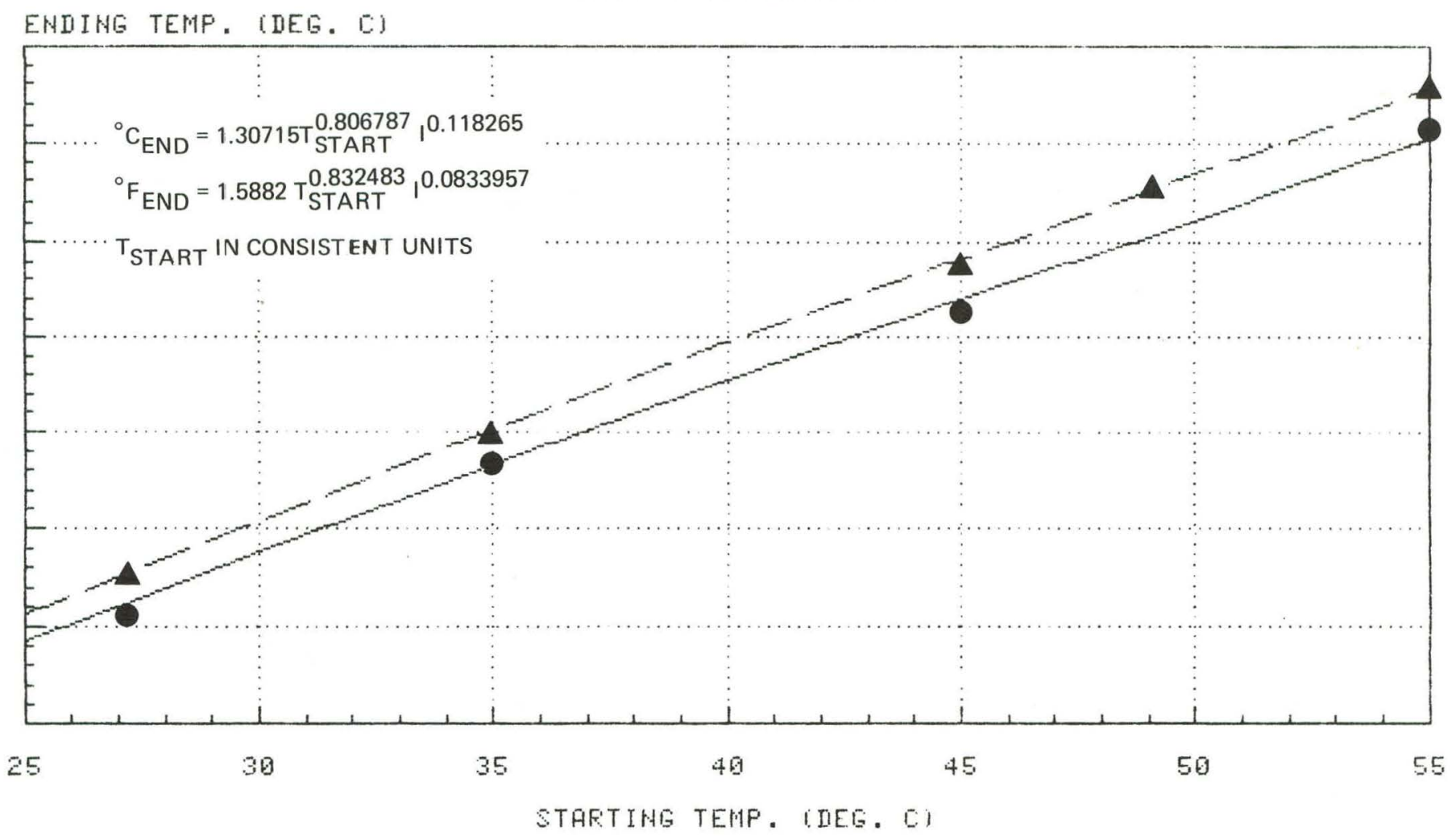

*DATA POINTS INDICATED ARE FROM TABLE 5-4.

Figure 5-5. Electrolyte Temperature Rise 
constant discharge current. These relationships were determined by the hot box air circulating system and the test philosophy to attempt to keep the electrolyte temperature constant. This information indicates how we 11 these series of tests were conducted. The accuracy between the test data and the synthesized equations 1 isted and plotted in Figure 5-5 is indicated in

Table 5-4 and illustrates that thermal management can be accomplished and the results of the effort can be accurately predicted.

Table 5-4. Curve Fit-to-Raw Data Differences, Electrolyte Temperature Rise

\begin{tabular}{ccccc}
\hline $\begin{array}{c}\text { Load } \\
\text { Current, A Temperature, }{ }^{\circ} \mathrm{C}\end{array}$ & $\begin{array}{c}\text { Estimated Ending Measured Ending } \\
\text { Temperature, }{ }^{\circ} \mathrm{C}\end{array}$ & $\begin{array}{c}\text { Semperature, }{ }^{\circ} \mathrm{C} \\
\text { Temifference, \% }\end{array}$ & Dert \\
\hline & & & & \\
75 & 27 & 30.80 & 30.86 & -0.19 \\
75 & 35 & 38.35 & 38.28 & 0.18 \\
75 & 45 & 46.98 & 46.33 & 1.40 \\
75 & 55 & 55.23 & 56.01 & -1.39 \\
110 & 27 & 32.23 & 32.15 & 0.25 \\
110 & 35 & 40.13 & 40.61 & -1.18 \\
110 & 45 & 49.15 & 48.80 & 0.72 \\
110 & 49 & 52.55 & 52.64 & -0.17 \\
110 & 55 & 57.79 & 57.56 & 0.57 \\
\hline
\end{tabular}




\section{SECTION VI}

VEHICLE LOAD TESTS AND ANALYSES

Table 6-1 lists the vehicle load test parameters and results; tests were conducted using a vehicle-as the test bed. The purpose of these tests was to establish the energy factor relating cutoff time to specific power and temperature. The GE ETV-1 was used as the test bed and the testing was performed using a chassis dynamometer to simulate the road load. These tests were conducted at 72 and $89 \mathrm{~km} / \mathrm{h}(45$ and $55 \mathrm{mi} / \mathrm{h})$ constant speed and using the J227a $D$ driving schedule. Both cosstdown testing and wind tunnel testing of this vehicle had been performed previously, allowing an accurate dynamometer setting to achieve a realistic road load.

Tables A-2b and A-3 (Appendix A) indicate the sequence of the vehicle load tests. Again, the baseline temperature tests $\left(27^{\circ} \mathrm{C}\right)$ were repeated throughout the sequence to ascertain that no detrimental effects occurred during the sequence.

Figure 6-1 shows specific power as a function of discharge time for several electrolyte starting temperatures. The analytical relationship chosen to represent these curves is an extension of the equation used by Brennand (Ref. 9) for simulating electric vehicles in ELVEC (Ref. 8). The constant power discharge tests required to determine the battery coefficients in the equation for specific power have previously been conducted by JPL and are described in Reference 10. The coefficients for the Exide EV IV battery are indicated in Figure 6-1.

Once the coefficients (A, B, C, and FACTOR in Figure 6-1) are known for a given type of battery, the effect of increased electrolyte temperature on vehicle range may be determined. For constant speed runs, the required specific power is constant and the discharge time (and hence the range) can be directly solved for (see Appendix C).

For other than constant speed runs, using the average specific power does not suffice. Fur these caoce, simulation using a program like ELVEC is required. The accuracy of the theoretical function versus the actual daca obtained is shown in Table 6-2 and the differences are about $5 \%$ or less, indicating that the model is quite adequate for predicting increased battery energy capacity as a function of discharge power and temperature. The energy benefit. with increase in temperature is, again, a three-space concept (illustrated in Figure 6-2). The factor indicated in Figure 6-1 of 0.0063 does not have units of percent per degrees centigrade as was the case for the temperature coefficient for ampere-hour capacity. Any rule of thumb for energy benefit must be a three-dimensional. rule of thumb. Table 6-3 emphasizes this point by listing energy capacity temperature coefficients in percent per degrees centigrade between discrete temperature bands. As can be seen from Table 6-3, the temperature coefficients are not constant. 
Table 6-1. Vehicle Load Test Data

\begin{tabular}{|c|c|c|c|c|c|c|c|c|c|c|}
\hline \multirow{2}{*}{\multicolumn{2}{|c|}{ Mode }} & \multicolumn{2}{|c|}{$\begin{array}{c}\text { Nominal } \\
\text { Temperature }\end{array}$} & \multicolumn{3}{|c|}{$\begin{array}{c}\text { Average Temperature, } \\
{ }^{\circ} \mathrm{C}\end{array}$} & \multirow{2}{*}{$\begin{array}{l}\text { Capa- } \\
\text { city, } \\
\text { A/h }\end{array}$} & \multirow{2}{*}{$\begin{array}{l}\text { Energy, } \\
\text { kWh }\end{array}$} & \multicolumn{2}{|c|}{ Distance } \\
\hline & & ${ }^{\circ} \mathrm{C}$ & ${ }^{\circ} \mathrm{F}$ & Start & End & Rise & & & $\mathrm{km}$ & $\mathrm{mi}$ \\
\hline 40 & $72.4 \mathrm{~km} / \mathrm{h}$ & 26.67 & 80 & 27.13 & 30.91 & 3.78 & 125.1 & 12.46 & 109.14 & 67.83 \\
\hline 41 & & & & 24.31 & 30.96 & 6.66 & 132.2 & 13.0 & 115.20 & 71.6 \\
\hline 51 & & & & 27.57 & 31.81 & 4.23 & 130.3 & 13.1 & 116.65 & 72.5 \\
\hline 52 & & & & 26.51 & 31.67 & 5.16 & 128.1 & .12 .9 & 115.20 & 71.6 \\
\hline 55 & & $\downarrow$ & $\downarrow$ & 27.36 & 32.48 & 5.12 & 127.9 & 12.9 & 115.04 . & 71.5 \\
\hline 45 & & 45.00 & 113 & 44.91 & 43.10 & -1.81 & 145.7 & 14.8 & 131.62 & 81.8 \\
\hline 48 & $\downarrow$ & $t$ & $\downarrow$ & 44.17 & 47.71 & 3.54 & 149.6 & 15.2 & 130.97 & 81.4 \\
\hline 39 & $88.5 \mathrm{~km} / \mathrm{h}$ & 26.67 & 80 & 25.63 & 31.43 & 5.80 & 113.6 & 11.12 & 84.73 & 52.66 \\
\hline 43 & & $t$ & 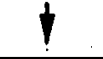 & 26.42 & 32.59 & 6.17 & 113.4 & 11.3 & 83.51 & 51.9 \\
\hline 46 & & 45.00 & 113 & 45.32 & 48.06 & 2.73 & 139.5 & 13.9 & 107.48 & 66.8 \\
\hline 50 & & 1 & 1 & 44.69 & 48.87 & $4.18^{\circ}$ & 134.7 & 13.3 & 99.11 & 61.6 \\
\hline 53 & $\downarrow$ & 55.00 & 131 & 54.77 & 58.81 & 4.04 & 139.8 & 13.8 & 103.14 & 64.1 \\
\hline 42 & $\mathrm{~J} 227 \mathrm{a} D$ & 26.67 & 80 & 25.77 & 39.17 & 13.40 & 125.5 & 11.7 & 61.14 & 38.0 \\
\hline 44 & & & 1 & 27.07 & 39.24 & 12.17 & 125.6 & 11.7 & 62.27 & 38.7 \\
\hline 56 & & 1 & $\downarrow$ & 27.05 & 38.28 & 11.23 & 122.1 & 11.5 & 62.11 & 38.6 \\
\hline 47 & & 45.00 & 113 & .45 .04 & 51.04 & 6.00 & 142.0 & 13.3 & 70.31 & 43.7 \\
\hline 49 & & 1 & 1 & 43.61 & 49.01 & 5.40 & 143.7 & 13.5 & 72.08 & 44.8 \\
\hline 54 & $\downarrow$ & 55.00 & 131 & 54.69 & 60.58 & 5.89 & 15.1 .7 & 14.3 & 77.39 & 48.1 \\
\hline
\end{tabular}




\section{SPECIFIC POUER VS CUTOFF TIME*}

(4 ELECTROLYTE STARTIHS TEMPERATURES)

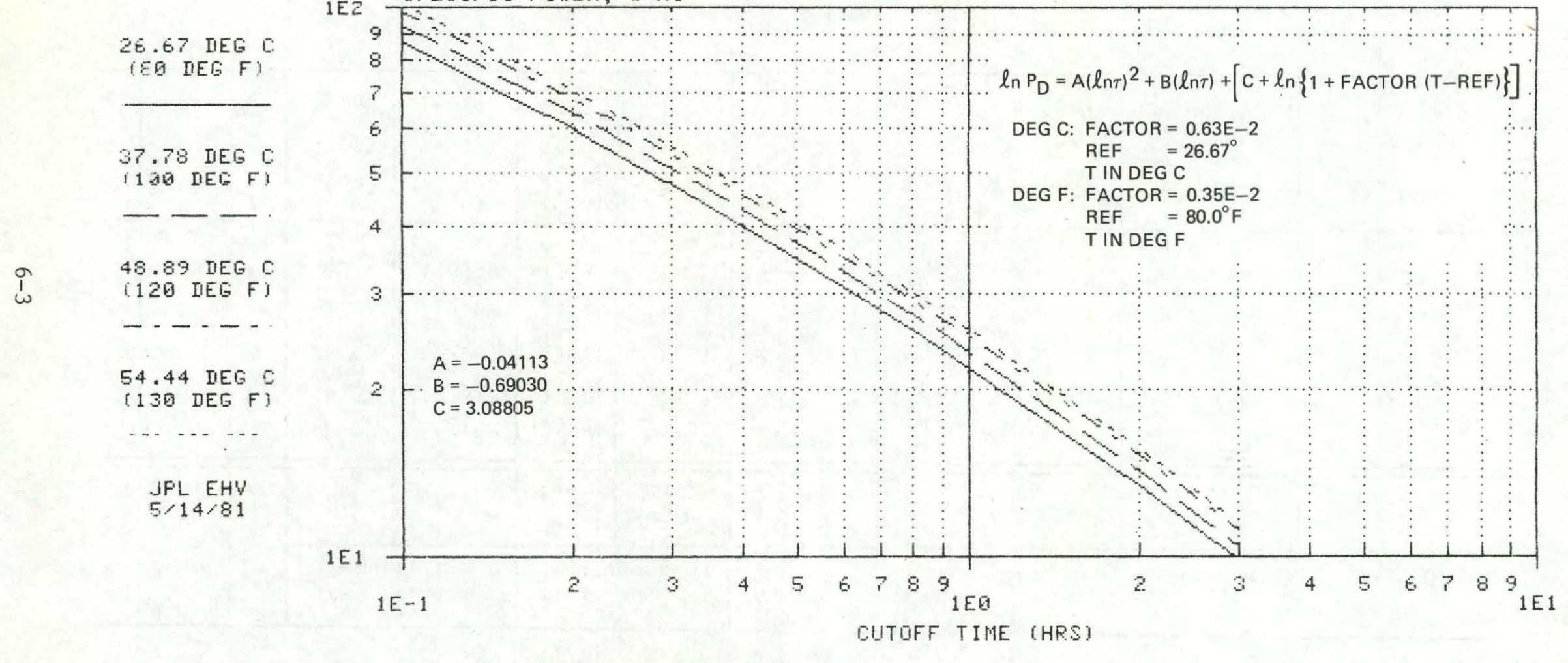

*SYNTHESIZED FROM THE DATA OF TABLE $6-1$. 
Table 6-2. Vehicle Load Test Versus Simulation

\begin{tabular}{|c|c|c|c|c|c|c|c|c|c|}
\hline $\mathrm{km} / \mathrm{h}$ & $\mathrm{mi} / \mathrm{h}$ & ${ }^{\circ} \mathrm{C}$ & ${ }^{\circ} \mathrm{F}$ & Test & $\begin{array}{l}\text { Simu- } \\
\text { lation }\end{array}$ & $\begin{array}{c}\text { kWh } \\
\% \\
\text { Difference }\end{array}$ & Test & Simulation & $\begin{array}{l}\text { Distance } \\
\% \text { Difference }\end{array}$ \\
\hline \multirow{2}{*}{$\begin{array}{c}72 \\
\downarrow\end{array}$} & \multirow{2}{*}{$\stackrel{45}{\downarrow}$} & 26.58 & 79.84 & 12.9 & 13.4 & 3.88 & $114.2(71.0)$ & $118.1(73.4)$ & 3.42 \\
\hline & & 44.54 & 112.17 & 15.0 & 15.5 & 3.33 & $131.3(81.6)$ & $136.6(84.9)$ & 4.04 \\
\hline 89 & 55 & 45.01 & 113.02 & 13.6 & 13.5 & -0.74 & $103.3(64.2)$ & $99.0(61.5)$ & $-4 \cdot 16$ \\
\hline$\gamma$ & $\downarrow$ & 54.77 & 130.59 & 13.8 & 14.5 & 5.07 & 103.1 (64.1) & $106.7(66.3)$ & 3.49 \\
\hline \multirow{2}{*}{\multicolumn{2}{|c|}{ J227a D }} & 26.63 & 79.93 & 11.6 & 11.0 & -5.17 & $61.8(38.4)$ & $61.5(38.2)$ & -0.49 \\
\hline & & 44.33 & 111.79 & 13.4 & 13.0 & -2.99 & $71.28(44.3)$ & $73.1(45.4)$ & 2.55 \\
\hline
\end{tabular}




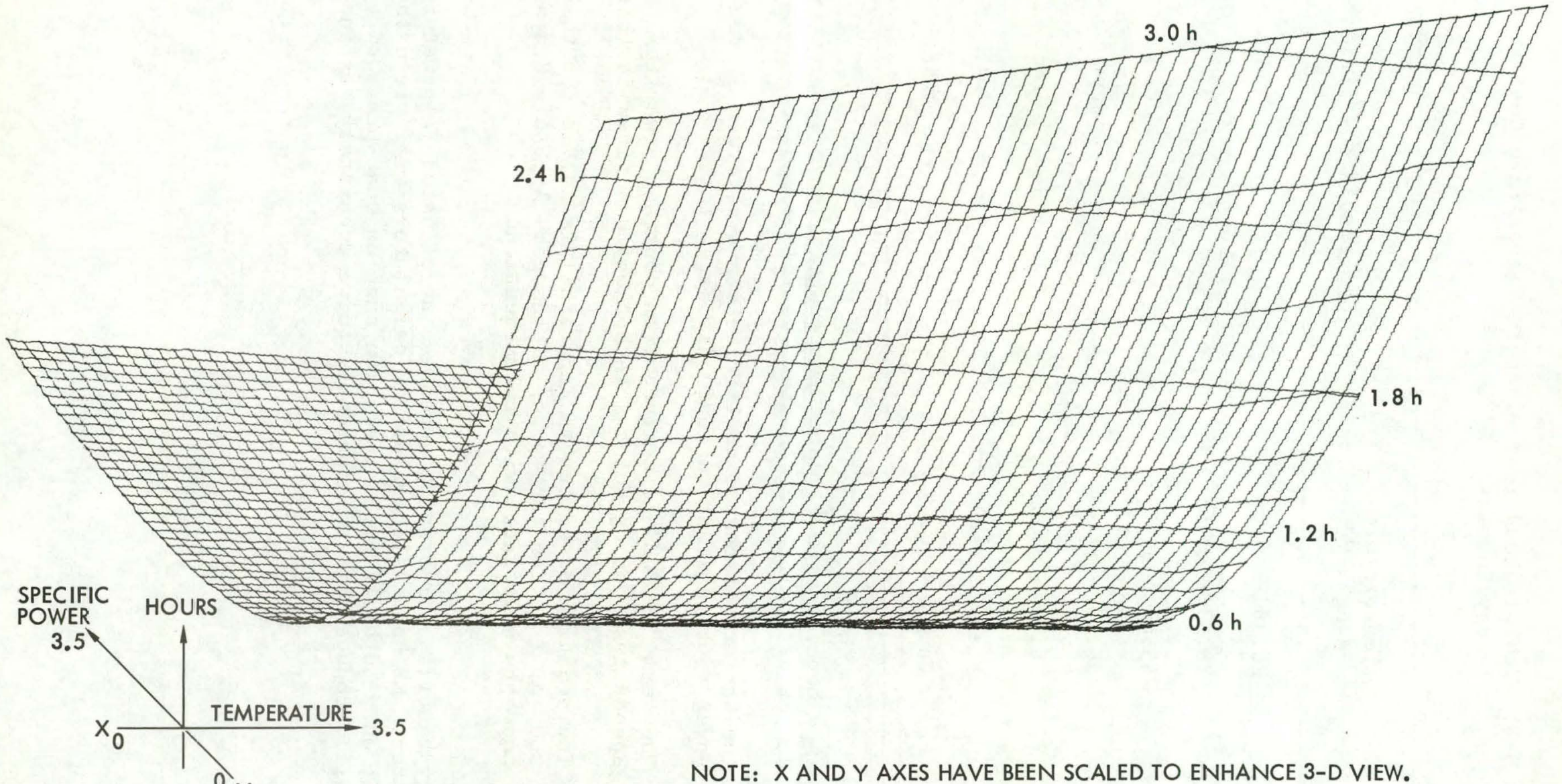

Figure 6-2. Discharge Time at Constant Power as a Function of Specific Power and Temperature 
Table 6-3. Vehicle Load Test Discrete Temperature Coefficients -Energy Increase, $\% /{ }^{\circ} \mathrm{C}$

\begin{tabular}{|c|c|c|}
\hline Mode & $\begin{array}{c}\text { Temperature } \\
\text { Range, }{ }^{\circ} \mathrm{C}\end{array}$ & Temperature Coefficients, $\% /{ }^{\circ} \mathrm{C}$ \\
\hline $72 \mathrm{~km} / \mathrm{h}$ & $26.58 \rightarrow 44.54$ & 0.91 \\
\hline \multirow[t]{3}{*}{89} & $26.03 \rightarrow 45.01$ & 1.13 \\
\hline & $45.01 \rightarrow 54.77$ & 0.15 \\
\hline & $26.03 \rightarrow 54.77$ & 0.81 \\
\hline \multirow[t]{3}{*}{ J227a D } & $26.63 \rightarrow 44.33$ & 0.88 \\
\hline & $44.33-54.69$ & 0.65 \\
\hline & $26.63 \rightarrow 54.69$ & 0.83 \\
\hline
\end{tabular}

The energy benefit with elevated temperature above a specified baseline temperature can be determined for constant vehicle speed if:

(1) The battery discharge coefficients are determined from constant power (not constant current) discharge tests.

(2) The term "FACTOR" is derived from constant power (or constant speed) tests using hot box technology described in this report.

(3) The equation described in Figure 6-1 is solved for the negative root of $\tau$ at constant power discharge. Appendix $C$ describes the concepts associated with this equation.

Energy benefits for driving schedules at elevated temperatures are another matter. No hand calculations or calculators will yield this information; only sophisticated simulation such as that provided by the ELVEC simulator will produce it, and apparently quite accurately, as indicated in Table 6-2. 


\section{SECTION VII}

\section{COMMENTS, CONCLUSIONS AND RECOMMENDATIONS}

To obtain the same energy and range benefits at baseline electrolyte temperature and while driving the GE ETV-1 at $89 \mathrm{~km} / \mathrm{h}(55 \mathrm{mi} / \mathrm{h})$, it would be necessary to:

(1) Reduce the zero speed rolling resistance from 1.26 to $0.88 \%$-- a reduction of $30 \%$, or

(2) Reduce the zero yaw drag coefficient frontal area product (CDA) from $0.567 \mathrm{~m}^{2}\left(6.1077 \mathrm{ft}^{2}\right)$ to $0.409 \mathrm{~m}^{2}\left(4.4 \mathrm{ft}^{2}\right)--\mathrm{a}$ reduction of $28 \%$, or

(3) Reduce the vehicle test weight from $1792 \mathrm{~kg}(3950 \mathrm{lb})$ to $1270 \mathrm{~kg}$ (2800 1b), keeping the same battery weight -- a reduction of $29 \%$.

Individually, none of the above is possible for a GE-type vehicle, but combinations of some of the above may be possible. On the other hand, running the battery pack at $55^{\circ} \mathrm{C}$ could increase the vehicle range over the SAE cycle by $25 \%$, but this approach may be detrimental to battery cycle life. Clearly, this conflict must be resolved.

Over the SAE J227a D driving schedule, the zero speed rolling resistance would have to be reduced to $0.90 \%$, and the zero yaw $\mathrm{CDA}$ reduced to $0.353 \mathrm{~m}^{2}$ (3.8 $\mathrm{ft}^{2}$ ) to obtain the same benefit as increasing the electrolyte temperature $28^{\circ} \mathrm{C}$. To look at it another way, the energy demand output of the battery would have to drop from about $0.18 \mathrm{kWh} / \mathrm{km}$ to $0.15 \mathrm{kWh} / \mathrm{km}$ for a $25 \%$ range increase.

The characteristics of this particular lead-acid battery pack and the mathematical relationships established in this report are probably not unique to the Exide IV batteries. Certainly, the coefficients and constants describing this particular pack will be unique, but the concepts, relationships, and trends should be representative of other types of electric vehicle lead-acid batteries available for motive power. It is imperative to determine the optimum temperature regime at which lead-acid batteries can be operated commensurate with acceptable cycle 1 ife and 1 ife-cycle costs. 
1. Graf, J.E., Toczylowski, J.F., and Chapman, P., "Elevated Temperature Lead-Acid Battery Pack Testing," paper presented at the Electric Vehicle Council Symposium IV, Baltimore, Maryland, October 1981 .

2. Bode, H., Lead-Acid Batteries, John Wiley and Sons, 1977.

3. Harbaugh, D., et al., The Rea1 Trouble with Lead-Acid EV Batteries (Informal Document), Southern California Edison Company, 1978.

4. Vinal, G.W., Storage Batteries, John Wiley and Sons, 1955.

5. Handbook for Battery Energy Storage in Photovoltaic Power Systems Final Report, Sandia Report SAND80-7022, May 1980, pp. 2-6, 3-24. (Report prepared by Bechtel National, Inc., San Francisco, for the U.S. Department of Energy, Contract DE-AC03-78ET26902.)

6. Maskalick, N.J., "Accelerated Life Testing of Lead-Acid Industrial Motive Power Cells," Journal of the Electrochemical Society; Vol. 122, No. 1, January 1975 .

7. Ohntrup, F.F., "Lead-Antimony or Lead-Calcium? Selecting a Standby Battery," Plant Engineering, October 31, 1974.

8. Slusser, R.S., "ELVEC - An Electric/Hybrid Vehicle Performance Simulation Computer Program," Electric Vehicle Council. Expo, May 1980 (EVC Paper No. 8053).

9. Brennand, J., et al., Electric and Hybrid Vehicle Performance and Design Goal Determination Study, U.S. Department of Energy, SAN/1215-1, August 1977 (General Research Corporation CR-1-734).

10. Chapman, P., "A Generic Battery Model for Electric and Hybrid Vehicle Simulation Performance Prediction," Electric Vehicle Council Expo, May 1980 (EVC Paper No. 8051). 
APPENDIX் A

TEST NUMBERS AND SEQUENCES 
Table A-1. Resistive Load Tests

\begin{tabular}{|c|c||c|}
\hline \multicolumn{2}{|c||}{ TEST CONFIGURATION } & \multicolumn{1}{c|}{$\begin{array}{c}\text { TEST } \\
\text { NIJMBERS }\end{array}$} \\
\hline \hline CURRENT, amps & TEMPERATURE, ${ }^{\circ} \mathrm{C}\left({ }^{\circ} \mathrm{F}\right)$ & $1,2,3,10,15$ \\
75 & $27(80)$ & 18,19 \\
$75(95)$ & 6,7 \\
75 & $45(113)$ & 11,12 \\
75 & $55(131)$ & $4,5,16,23$ \\
110 & $26(80) ;$ & 17,20 \\
110 & $35(95), 9,21$ \\
110 & $45(113)$ & 22 \\
110 & $49(120)$ & 13,14 \\
\hline
\end{tabular}


Tablè A-2. Test Sequence

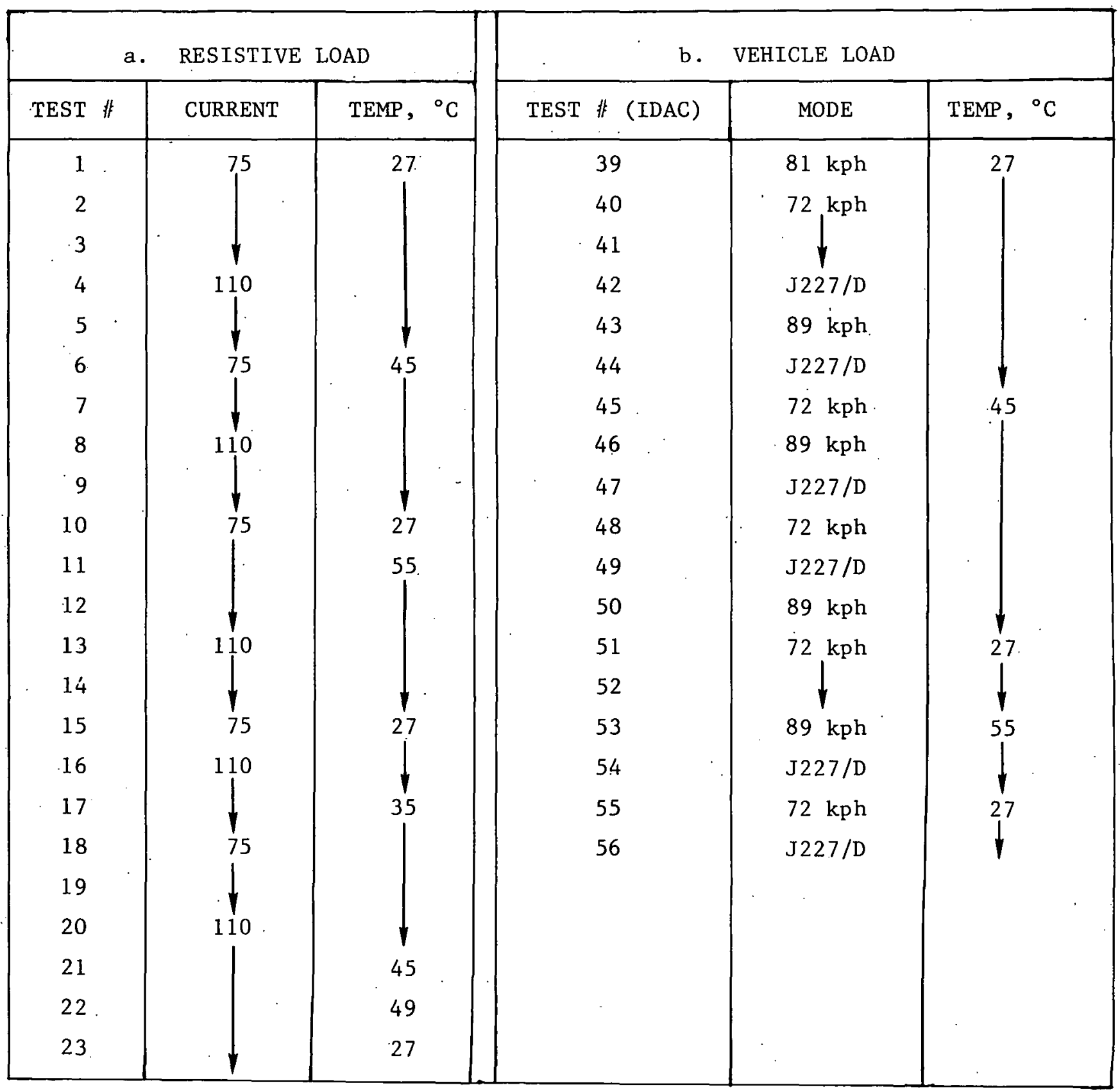


Table A-3. Vehicle Load Tests ${ }^{a}$

\begin{tabular}{|c|c|c|}
\hline \multicolumn{2}{|c|}{ TEST CONFIGURATION } & \multirow{2}{*}{ TEST NUMBERS } \\
\hline MODE & TEMPERATURE, ${ }^{\circ} \mathrm{C}\left({ }^{\circ} \mathrm{F}\right)$ & \\
\hline $72 \mathrm{kph}(45 \mathrm{mph})$ & $\begin{array}{l}27(80) \\
\dot{45}(113)\end{array}$ & $\begin{array}{l}40,41,51,52,55 \\
45,48\end{array}$ \\
\hline $89 \mathrm{kph}(55 \mathrm{mph})$ & $\begin{array}{ll}27 & (80) \\
45 & (113) \\
55 & (131)\end{array}$ & $\begin{array}{l}39,43 \\
46,50 \\
53\end{array}$ \\
\hline $\mathrm{SAE} J 227 \mathrm{a} / \mathrm{D}$ & $\begin{array}{l}27(80) \\
45(113) \\
55(131)\end{array}$ & $\begin{array}{l}42,44,56 \\
47,49 \\
54\end{array}$ \\
\hline
\end{tabular}

${ }^{a}$ Vehicle was the DOE/General Electric ETV-1. 
APPENDIX B

CONSTANT CURRENT DISCHARGE EQUATION DEVELOPMENT 


\section{APPENDIX B \\ CONSTANT CURRENT DISCHARGE EQUATION DEVELOPMENT}

Consider the plot of discharge time versus discharge rate of a typical lead-acid battery at temperature $\mathrm{T}$.

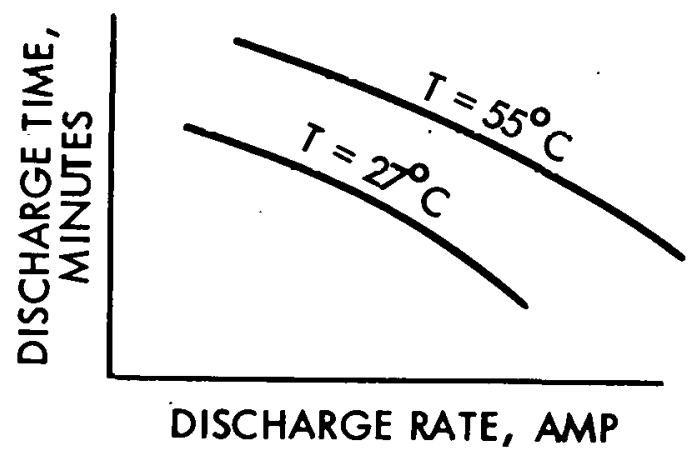

The plot indicates a power function of the form:

$$
y=a x^{b}
$$

where $a$ and $b$ are the curve fit constants for the function at a specified temperature, as indicated in the above plot. These constants are known as the Peukert constants ${ }^{1}$ by tradition in the electro-chemical field but modern students of engineering will recognize equation ( $B-1$ ) as nothing more than a power equation.

$1_{\text {PEUKERT, }}$ W., "On the dependence of the capacity of lead-accumulators on the discharge current," ELEKTRO-TECHNISCHE Z., (ETZ), 1897, 18, pp. 287,288. 
If the ordinate axis ( $y$ axes) is converted to hours rather than minutes and if each value of $\mathrm{y}$ is multiplied by the corresponding value of $\mathrm{x}$, the ordinate axis acquires units of amp-hours rather than just discharge time. The form of equation (B-1) becomes:

$$
\mathrm{AH}(\mathrm{I})=\mathrm{kI} \mathrm{I}^{\mathrm{n}}
$$

where $k$ and $n$ are again the curve fit constants at a specified electrolyte temperature. These constants are also historically known as the Peukert Constants and the functions indicated in the plot and the modifications thereof are called (again, by tradition) the Peukert Curves.

For lead-acid batteries it is purported that the amp-hour capacity of a battery increases by a percentage "factor" per ${ }^{\circ} \mathrm{C}$. Therefore, an additional temperature term can be attached to equation ( $B-2)$ of the form:

$$
\operatorname{AH}(I, T)=k I^{n}[1+(\text { FACTOR })(T-R E F)]
$$

where

$I$ is in amps,

$T$ and REF have consistent units of temperature, REF being the reference temperature at which the curve fit constants $k$, $n$ were determined.

FACTOR is a constant (\% per degree $\mathrm{C}$ )/100 or variable determined by experiment.

Equation (B-3) can be solved for time, in hours:

$$
t(I, T)=k I^{n-1}[1+(\text { FACTOR })(T-R E F)]
$$


The amp-hour and current data were used in Table 5-1 at $26.67^{\circ}$ to determine the constants $k$ and $n$. Since only two currents were available, it was necessary beforehand to know the form of the equation in order to get the traditional curve fit.

FACTOR is just the slope of the locus of points in Figure 5-1. 
APPENDIX C

DISCHARGE EQUATION FOR ALL LEAD-ACID BATTERIES 
APPENDIX C

DISCHARGE EQUATION FOR ALL LEAD-ACID BATTERIES

The discharge equation for any lead-acid battery is of the form: ${ }^{1}$

$$
\ln P_{D}=A(\ln \tau)^{2}+B(\ln \tau)+\{C+\ln [1+\operatorname{FACTOR}(T-R E F)]\}
$$

and, in particular, the only solution of interest is:

$$
\tau=\operatorname{EXP} \frac{-B-\left[B^{2}-4 A\left\{C+\ln \frac{[1+\operatorname{FACTOR}(T-R E F)]}{P_{D}}\right\}\right]}{2 A}
$$

where

$\ell n$ : natural log function

$\mathrm{P}_{\mathrm{D}}$ : specific power density, $\mathrm{W} / \mathrm{kg}$

FACTOR: 0.0063 '(from F1.gure 6-1)

$\mathrm{T}$ : starting electrolyte temperature, ${ }^{\circ} \mathrm{C}$

REF: roference temperature at which coefficients $A, B$, and $C$ are determined

$\tau$ : time to cutoff at constant power (density) discharge. $\tau$ has units of hours.

$\mathrm{A}, \mathrm{B}$, and $\mathrm{C}$ are the battery discharge coefficients and must be determined at a baseline temperature from constant power (or constant speeds - if a vehicle load is available) tests. Coefficients A and B are temperature insensitive at least between $27^{\circ}$ and $55^{\circ} \mathrm{C}$. Coefficient $\mathrm{C}$ is temperature dependent and its effect Is to translate the function described by equation (C-1) up and down the ordinate axes without translation along the abscissa.

$\overline{I_{\text {See }} \text { Reference } 9 .}$ 
The battery discharge coefficients are determined by a least squares fit algorithm from the constant power discharge tests, using several different specific powers (the $\mathrm{P}_{\mathrm{D}_{i}}$ 's) resulting in different cutoff time (the $\tau_{i}$ 's). The form of the algorithm is:

$$
\left[\begin{array}{ccc}
\Sigma\left(\ln \tau_{i}\right)^{4} & \Sigma\left(\ln \tau_{i}\right)^{3} & \Sigma\left(\ln \tau_{i}\right)^{2} \\
\Sigma\left(\ln \tau_{i}\right)^{3} & \Sigma\left(\ln \tau_{i}\right)^{2} & \Sigma\left(\ln \tau_{i}\right) \\
\Sigma\left(\ln \tau_{i}\right)^{2} & \Sigma\left(\ln \tau_{i}\right) & \Sigma(l)
\end{array}\right]\left[\begin{array}{l}
A \\
B \\
C
\end{array}\right]=\left[\begin{array}{lll}
\Sigma \ln \mathrm{P}_{\mathrm{D}_{i}}\left(\ln \tau_{i}\right)^{2} \\
\Sigma \ln \mathrm{P}_{\mathrm{D}}\left(\ln \tau_{i}\right) \\
\Sigma \ln \mathrm{P}_{\mathrm{i}} &
\end{array}\right]
$$

